Лопушинський Іван Петрович доктор наук 3 державного управління, професор, заслужений працівник освіти України, завідувач кафедри державного управління і місцевого самоврядування Херсонського національного технічного університету, Бериславське Шосе, 24, Херсон, Херсонська область, 73008, тел.: (095) 515-73-49, e-mail: doctordumetaua@meta.ua, https://orcid.org/0000-0002-7460-7476

Бондарева Ліна Володимирівна кандидат наук 3 державного управління, доцент кафедри державного управління і місцевого самоврядування Херсонського національного технічного університету (за сумісництвом), заступник директора Департаменту здоров'я Херсонської обласної державної адміністрації, 149н.149. 295-ї Стрілецької дивізії, 21, м. Херсон, 73003, тел.: (050) 631-43-49, e-mail: linabondareva2006@gmail.com, https://orcid.org/0000-0002-5025-0759

Дурман Микола Олександрович доктор наук 3 державного управління, доцент, заслужений працівник освіти України, професор кафедри державного управління і місцевого самоврядування Херсонського національного технічного університету, Бериславське Шосе, 24, Херсон, Херсонська область, 73008, тел.: (050) 315-03-73, e-mail: mykola.durman@gmail.com, https://orcid.org/0000-0002-3775-205X

\title{
РЕГІОНАЛЬНА ПОЛІТИКА УКРАЇНИ ЩОДО ЗАПОБІГАННЯ ТА ПРОТИДІЇ ЕПІДЕМІЇ ТУБЕРКУЛЬОЗУ: МЕХАНІЗМИ ФОРМУВАННЯ ТА РЕАЛІЗАЦЇ̈ (НА ПРИКЛАДІ ХЕРСОНСЬКОЇ ОБЛАСТІ)
}

Анотація. У статті на конкретному матеріалі констатується, що Україна і надалі залишається однією із п'яти країн 3 найвищим рівнем захворюваності на мультирезистентний (форма туберкульозу, що резистентна (від лат. resistentia) «опірність», «здатність чинити опір чому-небудь» - 149н.149.). до щонайменше двох найбільш ефективних протитуберкульозних препаратів) туберкульоз у Східній Європі та Центральній Азії (2014 року Україна вперше ввійшла до п’яти країн світу з найвищим рівнем захворюваності на хіміорезистентний туберкульоз (форму туберкульозу, при якій пацієнт виділяє мікобактерії туберкульозу, резистентні до одного або більшої кількості протитуберкульозних препаратів, що підтверджено лабораторним методом в тесті медикаментозної чутливості (ТМЧ 149н.149.); попри те, що впродовж останніх п’яти років в Україні спостерігається 
тенденція до зниження рівня захворюваності на туберкульоз, показано, що епідемічна ситуація з туберкульозом (ТБ) у світі в цілому та в Україні зокрема залишається складною та на цьому етапі (початок 20-х років XXI століття) має певні особливості; переконливо доведено, що прогнози щодо подолання ТБ найближчим часом $\epsilon$ досить сумнівними, хоча й, як зазначалося вище, зберігається тенденція до зменшення захворюваності на туберкульоз, проте має місце низка складних і суперечливих питань щодо ліквідації цього інфекційного захворювання згідно зі стратегією ВООЗ End TВ; розкрито, що відповідно до національного законодавства протидія захворюванню на туберкульоз є складовою державної політики щодо забезпечення якісної і доступної медичної допомоги, реалізації державних цільових програм лікування найбільш поширених небезпечних для здоров'я і життя людини захворювань, проведення обов'язкових профілактичних медичних оглядів 3 метою ранньої діагностики захворювань, надання гарантованого обсягу безоплатної медичної допомоги; показано, що завершення виконання Загальнодержавної цільової соціальної програми протидії захворюванню на туберкульоз на 2012-2016 роки, відповідних регіональних та місцевих програм на ці та наступні роки, зокрема Херсонської області й міста Херсона, сприяло те, що фінансування заходів, передбачених програмами, здійснюється не повним обсягом, що призводить до невиконання завдань, отже, невиконання повним обсягом цільових показників програм; доведено, що органи публічної влади регіонального рівня (державного управління i місцевого самоврядування) мають докласти всіх зусиль задля докорінної зміни ситуації 3 поширенням туберкульозу з тим, щоб у найближчій перспективі досягти бажаних позитивних результатів у боротьбі з цією соціально небезпечною інфекційною хворобою; запропоновано розглядати протидію туберкульозу не як систему медичних заходів, а як складну комплексну політичну, управлінську, економічну, соціальну, медичну, гуманітарну, культурну тощо проблему, вирішення якої лише медичними засобами та галузевим медичним управлінням не є ефективним.

Ключові слова: туберкульоз, епідемія туберкульозу, епідеміологічна ситуація, механізми формування та реалізації регіональної політики щодо запобігання та протидії епідемії туберкульозу, органи публічної влади регіонального рівня, регіональні органи управління системою охорони здоров’я.

Lopushynskyi Ivan Petrovych Doctor of Science in Public Administration, Professor, Honored Worker of Education of Ukraine, Head of the Department of Public Administration and Local Self-Government of Kherson National Technical University, Beryslavske Shosse, 24, Kherson, Kherson region, 73008, tel.: (095) 515-73-49, e-mail: doctordumetaua@meta.ua, https://orcid.org/0000-0002-7460-7476 
Bondareva Lina Volodymyrivna Candidate of Sciences in Public Administration, Associate Professor of the Department of Public Administration and Local SelfGovernment of Kherson National Technical University (part-time), Deputy Director of the Department of Health of Kherson Regional State Administration, Kherson, 295th Rifle Division St., 21, 73003, tel.: (050) 631-43-49, e-mail: linabondareva2006@gmail.com, https://orcid.org/0000-0002-5025-0759

Durman Mykola Oleksandrovych $\mathrm{PhD}$ of Information Technology, Docent, Honored Worker of Education of Ukraine, Professor of the Department of Public Administration and Local Self-Government of Kherson National Technical University, Beryslavske Shosse, 24, Kherson, Kherson region, 73008, tel.: (050) 315-03-73, e-mail: mykola.durman@gmail.com, https://orcid.org/0000-0002-3775-205X

\section{REGIONAL POLICY OF UKRAINE REGARDING PREVENTION AND CONTROL OF THE TUBERCULOSIS EPIDEMIC: MECHANISMS OF FORMATION AND IMPLEMENTATION (ON THE EXAMPLE OF THE KHERSON REGION)}

Abstract. The article states that Ukraine continues to be one of the five countries with the highest incidence of multidrug-resistant (a form of tuberculosis that is resistant) (from Latin resistentia) - «resistance», «ability to resist something» - author). to at least two of the most effective anti-TB drugs) tuberculosis in Eastern Europe and Central Asia (in 2014, Ukraine was among the five countries in the world with the highest incidence of chemoresistant tuberculosis the number of anti-TB drugs, which is confirmed by a laboratory method in the drug sensitivity test (DST - author), despite the fact that over the past five years in Ukraine there has been a tendency to reduce the incidence of tuberculosis, it is shown that the epidemic situation with tuberculosis (TB) in the world in general and in Ukraine in particular remains difficult and at this stage (early 20s of the XXI century) has certain features, it is convincingly proven that the forecasts for overcoming TB in the near future are quite doubtful, although, as noted above, to reduce the incidence of tuberculosis, but there are a number complex and controversial issues regarding the eradication of this infectious disease in accordance with the WHO End TB strategy; It is revealed that in accordance with national legislation, the fight against tuberculosis is part of state policy to ensure quality and affordable medical care, the implementation of state targeted programs for the treatment of the most common diseases dangerous to human health and life, mandatory preventive medical examinations for early diagnosis of diseases, provision of a guaranteed amount of free medical care; It is shown that the completion of the National Targeted Social 
Program for TB Control for 2012-2016, relevant regional and local programs for these and subsequent years, in particular the Kherson region and the city of Kherson, contributed to the fact that funding for measures provided by the programs is not complete volume, which leads to non-fulfillment of tasks, therefore, non-fulfillment of the full target indicators of programs; it is proved that public authorities at the regional level (public administration and local self-government) should make every effort to radically change the situation with the spread of tuberculosis in order to achieve the desired positive results in the near future in the fight against this socially dangerous infectious disease; It is proposed to consider the fight against tuberculosis not as a system of medical measures, but as a complex political, managerial, economic, social, medical, humanitarian, cultural, etc. problem, the solution of which only by medical means and branch medical management is not effective.

Keywords: tuberculosis, tuberculosis epidemic, epidemiological situation, mechanisms of formation and implementation of regional policy on prevention and counteraction of tuberculosis epidemic, public authorities of regional level, regional authorities of health care system management.

Постановка проблеми. 1993 року ВООЗ вперше в своїй історії почала бити на сполох і визнала туберкульоз глобальною небезпекою та повідомила, що якщо уряди країн не вважатимуть боротьбу 3 туберкульозом своїм найпершим пріоритетом i не будуть фінансувати боротьбу 3 цим захворюванням, то туберкульоз нанесе колосальних збитків економікам і населенню нашої планети. Зважаючи на такий стан справ, високорозвинені країни відразу ж виділили значні кошти на подолання епідемії туберкульозу і вже через 1-3 роки взяли під контроль над ситуацією з туберкульозом у своїх країнах. Бідні ж країни не змогли профінансувати протитуберкульозні заходи, й епідемія туберкульозу в них прогресувала орієнтовно аж до 2005 року, і лише, починаючи з 2006 року, у більшості цих країн, як і в Україні, епідемія туберкульозу почала повільно відступати.

Аналіз доступної публічної бази даних наукових джерел засвідчив, що загальна кількість хворих на туберкульоз (ТБ) в останні роки була відносно стабільною, хоча тягар поширеності хвороби сильно різниться серед сукупності країн: від меншої кількості в країнах з високим рівнем економіки - більше 5 та до понад 500 нових випадків на 100 тис. населення на рік у країнах 3 низьким економічним рівнем розвитку. Середній показник у світі становить близько 130 на 100 тис. населення [1]. Статистичний аналіз, опублікований у рапорті Всесвітньої організації охорони здоров'я (ВООЗ) 2019 р., показав, що в усьому світі 2018 р. захворіли на ТБ майже 10,0 млн осіб (діапазон 9,0-11,1 млн). Отже, попри позитивні результати, досягнуті в питанні подолання туберкульозної інфекції (ТI), 
епідеміологічна ситуація з ТБ у світі та в Україні залишається складною та на сьогодні має певні особливості, а прогноз щодо іiі подолання найближчим часом $\epsilon$ досить сумнівним.

Водночас захворюваність на туберкульоз в Україні на 32\% вища від середньоєвропейської. Епідемію туберкульозу в Україні вперше було зареєстровано 1995 року. Саме тому туберкульоз у нашій державі наразі залишається серйозною проблемою у сфері охорони здоров'я. Так, 2018 року в Україні від цієї хвороби щодня помирало 10 людей. Україна має один із найвищих рівнів захворюваності на хіміорезистентний туберкульоз у світі та посідає третє місце у світі за абсолютною кількістю зареєстрованих випадків туберкульозу 3 розширеною резистентністю.

4-5 березня 2020 року Міністерство охорони здоров’я України у партнерстві з міжнародною організацією «Лікарі без кордонів» провело перший в Україні (9-й за порядком - 153н.153.) регіональний симпозіум 3 питань лікування туберкульозу під назвою «Подолання перешкод у лікуванні туберкульозу: від стратегії до дій» [2]. Під час симпозіуму було розглянуто питання лікування та труднощів при лікуванні туберкульозу в країнах Східної Свропи та Центральної Азії. Зокрема, серед 160 учасників були представники BOO3, USAID, експерти у сфері боротьби з туберкульозом зі США, Франції, Німеччини та інших європейських країн, а також українські неурядові організації.

Аналіз останніх досліджень і публікацій. До проблеми запобігання i протидії захворюванню на туберкульоз упродовж останніх трьох років (20182020) у своїх наукових розвідках зверталися: К.Ф. Марквас (проаналізовано досвід боротьби з туберкульозом на півдні України у міжвоєнний період (за матеріалами Херсонщини, 2018) [3], Ю.І. Фещенко (розглянуто сучасні тенденції вивчення проблем туберкульозу, 2019) [4], К. О. Талалаєв, В. С. Гойдик, Р. С. Вастьянов, А. В. Тодорова (153н.153153остов динаміку змін епідемічної ситуації з туберкульозу в областях Причорноморського регіону та в Україні в період з 2006 до 2018 р., 2019) [5], Ю. І. Фещенко, В. М. Мельник, М. І. Гуменюк, М. І. Линник (вивчено епідеміологічну ситуацію з туберкульозу в Україні, 2019) [6], Л. Д. Тодоріко, М. І. Гуменюк, О. С. Шевченко, І. В. Сременчук, І. О. Сем’янів (здійснено прогностичний аналіз ситуації з туберкульозу у світі за результатами щорічної доповіді ВОО3, 2019) [7], А. М. Нагорна, І. Г. Кононова, М. П. Соколова (проаналізовано нормативно-правове регулювання профілактики та надання медичної допомоги хворим на загальний і професійний туберкульоз в Україні, 2020) [8], Л. Д. Тодоріко, В. І. Петренко, Ю. М. Валецький, О. С. Шевченко, I. О. Сем'янів, І. Я. Макойда, М. І. Сахелашвілі, Грищук. А. Л (показано досягнення та складні питання щодо подолання туберкульозу в Україні (консолідований погляд 3 різних регіонів), 2020) [9] та 153н.. Водночас названі 
вище вчені переважно $є$ фахівцями в галузі медицини. У галузі ж науки державного управління по суті відповідних публікацій не було.

Формування мети дослідження полягало в тому, щоб підсумувати досягнення органів публічної влади регіонального рівня та визначити складні питання щодо подолання туберкульозу у світі в цілому, в Україні та на регіональному рівні зокрема (на прикладі Херсонської області) на етапі сьогодення, що потребує від органів державної влади та органів місцевого самоврядування більшої уваги, детальнішого вивчення чи зміни підходів до вирішення окремих завдань на шляху до реалізації стратегічних глобальних цілей щодо ліквідації цієї вкрай соціально небезпечної інфекції.

Виклад основного матеріалу. Відповідно до Закону України «Про протидію захворювання на туберкульоз» [10] «туберкульоз - соціально небезпечна інфекційна хвороба, що викликається мікобактеріями туберкульозу» [10].

Законодавство України у сфері протидії захворюванню на туберкульоз складається 3 Основ законодавства України про охорону здоров'я, законів України «Про забезпечення санітарного та епідемічного благополуччя населення», «Про протидію поширенню хвороб, зумовлених вірусом імунодефіциту людини (ВІЛ), та правовий і соціальний захист людей, які живуть 3 ВІЛ», «Про захист населення від інфекційних хвороб», «Про протидію захворювання на туберкульоз» [10], інших нормативно-правових актів, прийнятих відповідно до них, зокрема розпорядження Кабінету Міністрів України від 22 березня 2017 року № 248-р «Про схвалення Стратегії забезпечення сталої відповіді на епідемії туберкульозу, в тому числі хіміорезистентного, та ВІЛінфекціі/СНІДу на період до 2020 року та затвердження плану заходів щодо іï реалізації» [11].

Протидія захворюванню на туберкульоз $є$ складовою державної політики щодо забезпечення якісної і доступної медичної допомоги, реалізації державних цільових програм лікування найбільш поширених небезпечних для здоров’я i життя людини захворювань, проведення обов’язкових профілактичних медичних оглядів з метою ранньої діагностики захворювань, надання гарантованого обсягу безоплатної медичної допомоги.

Як закріплено в Законі [10], здійснення протитуберкульозних заходів, забезпечення кожному громадянину в разі захворювання на туберкульоз безоплатності, доступності та рівних можливостей отримання відповідної медичної допомоги належать до завдань центральних i місцевих органів виконавчої влади, органів місцевого самоврядування [10].

Відповідно до Закону [10] місцеві органи виконавчої влади у сфері протидії захворюванню на туберкульоз в межах своїх повноважень: 1) забезпечують реалізацію державної політики у сфері протидії захворюванню на туберкульоз, 
організовують розроблення i виконання відповідних регіональних та місцевих програм, беруть участь у розробленні та виконанні державних програм; 2) забезпечують відповідно до закону виконання заходів соціального захисту хворих на туберкульоз та малолітніх і неповнолітніх осіб, інфікованих мікобактеріями туберкульозу; 3) здійснюють протитуберкульозні заходи та контролюють їх виконання юридичними і фізичними особами; 4) інформують населення через засоби масової інформації про епідемічну ситуацію щодо захворюваності на туберкульоз у регіоні та заходи, що здійснюються 3 метою іiі поліпшення; 5) організують забезпечення кадровими, фінансовими та матеріально-технічними ресурсами комунальні протитуберкульозні заклади [10].

Органи місцевого самоврядування у сфері протидії захворюванню на туберкульоз: 1) затверджують місцеві програми протидії захворюванню на туберкульоз, здійснюють їх матеріально-технічне і фінансове забезпечення та контроль за їх виконанням; 2) забезпечують виконання передбачених законом заходів соціального захисту хворих на туберкульоз; 3) здійснюють інші повноваження, визначені законом [10].

27 грудня 2017 року Уряд України схвалив Концепцію Загальнодержавної цільової соціальної програми протидії захворюванню на туберкульоз на 2018-2021 роки [12]. Метою Документа є стабілізація рівня захворюваності, зменшення рівня смертності та підвищення ефективності лікування хворих. Ухвалення програми, на думку урядовців, допоможе досягти цілей Плану дій по боротьбі 3 туберкульозом для Європейського регіону ВООЗ на 2016-2020 роки, сприяючи тим самим досягненню мети глобальної стратегії «Покласти кінець ТБ» зупинити епідемію туберкульозу, а саме до 2035 року: на 95\% зменшити смертність від ТБ порівняно з 2015 роком, досягти рівня захворюваності менше 10 на 100 тисяч та $з$ нульовим рівнем страждань від ТБ. До 2050: досягти нульового рівня смертності від туберкульозу та нульового рівня захворюваності [12].

Виконання програми також дасть змогу забезпечити: 100\% доступ до неперервної діагностики ТБ шляхом закупівлі витратних матеріалів, 100\% доступ до лікування всіх хворих на ТБ шляхом впровадження пацієнтоорієнтованого підходу, 100\% доступ до консультування та тестування на ВІЛ/СНІД тощо.

Відповідно до статті 93 Конституції України 14 січня 2019 року Кабінет Міністрів України в порядку законодавчої ініціативи подав до Верховної Ради України для розгляду парламентом 155н.155155o Закону України «Про затвердження Загальнодержавної цільової соціальної програми протидії захворюванню на туберкульоз на 2018-2021 роки, зареєстрований за № 9467 [13], що, на жаль, не розглянутий і до цього часу. Як зазначалося в 155н.155155oc, метою Програми є стабілізація рівня захворюваності, зменшення рівня смертності та підвищення ефективності лікування хворих на чутливий туберкульоз, 
хіміорезистентний туберкульоз, ко-інфекцію (туберкульоз/ВІЛ-інфекція/СНІД), забезпечення загального та рівного доступу населення до якісних послуг 3 профілактики, діагностики і лікування туберкульозу [13].

Як видно, Українська держава на рівні нормативно-правового забезпечення намагається докласти максимум зусиль до боротьби 3 такою соціально небезпечною хворобою, якою є туберкульоз. Водночас, як було сказано вище, результати реалізації цих документів досить скромні. Передусім слід відзначити, що незадовільна ситуація з туберкульозу на 90\% залежить від соціальноекономічних чинників, від влади, від політиків і лише на $10 \%$ - від медицини, від діяльності медичних працівників. Як зазначає Ю.І. Фесенко, до соціальноекономічних й політичних чинників незадовільної ситуації з туберкульозу слід віднести: 1) соціально-економічну кризу в країні, що призвела до: погіршення добробуту й освіченості народу; стресів, бідності, безробіття; зростання алкоголізму, наркоманії, токсикоманії, бездомних, жебраків та інших соціально дезадаптованих верств населення; збільшення чисельності осіб у пенітенціарній системі; міграції населення і зростання груп ризику щодо туберкульозу. Крім того, соціально-економічна криза призвела й до погіршення фінансування охорони здоров'я, до кризи охорони здоров'я і непристосованості охорони здоров'я до ринкових умов, а це, своєю чергою, призвело до: кадрової кризи (понад $60 \%$ лікарів-фтизіатрів глибокого пенсійного віку); до поганого забезпечення лікувально-профілактичних закладів медичною апаратурою, обладнанням, ліками, соціальною підтримкою хворих; неналежних санітарногігієнічних умов перебування i поганого харчування хворих у стаціонарах; недоступності медичної допомоги для більшості населення, особливо сільського; нестачі антимікобактеріальних, патогенетичних і симптоматичних препаратів; недоступності фтизіохірургічного лікування хворих через погане фінансування фтизіохірургічної допомоги [4].

Усі ці соціально-економічні й політичні чинники та криза охорони здоров'я призвели до: відсутності реформування, реорганізації та реструктуризації охорони здоров'я загалом і протитуберкульозної служби зокрема; невиконання через брак фінансування повним обсягом протитуберкульозних заходів; прогресування епідемії туберкульозу і ВІЛ/СНІДу, у т. ч. хіміорезистентного туберкульозу та коінфекції туберкульозу/ВІЛ/СНІДу як серед всього населення, так i в пенітенціарній системі (на Херсонщині - особливо - 156н.156.), серед тих, що звільнилися з ув'язнення, бездомних, мігрантів, біженців та знедолених [4].

Водночас міжнародний досвід організації державних заходів щодо запобігання розвитку соціально небезпечних хвороб свідчить про те, що сфера відповідальності держави за дотримання епідемічного благополуччя населення більш ефективна тоді, коли вона поділена між центральними органами виконавчої 
влади та відповідними інстанціями на місцях, які безпосередньо не належать до медичної галузі (охорони здоров’я), а $є$ керованою іншими відомствами, наприклад, у сфері охорони природи, сільського господарства, енергетики, надзвичайних ситуацій, внутрішніх справ, соціальної політики, освіти тощо. Більше того, цей досвід вказує на те, що питання відповідальності суб'єктів управління за здійснення заходів соціальної профілактики туберкульозу бажано імплементувати в діяльність практично кожного міністерства (служби, агентства, інспекції, департаменту, управління тощо). При цьому, галузеве державне управління у сфері протидії захворюванню на туберкульоз продовжує здійснюватися виключно в межах організації медичної профілактики, медичної та соціальної допомоги, організації санітарної освіти та виховання населення.

3 огляду на такі обставини фахівцями Громадського руху «Українці проти туберкульозу» було розроблено Концепцію загальнодержавної і регіональної міжвідомчої та 157н.157157остовано157ої координації діяльності в сфері протидії епідемії туберкульозу. Цю Концепцію спрямовано на створення сприятливих суспільно-політичних умов для всебічного захисту населення України від туберкульозу, забезпечення ефективного державного контролю епідемічної ситуації, скорочення рівня захворюваності, поширеності та смертності від цієї особливо небезпечної соціальної інфекційної хвороби, подолання соціальноекономічних, політичних, медичних, культурних та інших чинників і наслідків епідемії туберкульозу в Україні.

Проте основною новизною Концепції $є$ те, що вона, уперше за часи епідемії туберкульозу в України, пропонує розглядати протидію туберкульозу не як систему медичних заходів, а як складну комплексну політичну, управлінську, економічну, соціальну, медичну, гуманітарну, культурну тощо проблему, вирішення якої лише медичними засобами та галузевим медичним управлінням не $\epsilon$ ефективним.

На основі Концепції було розроблено: 157н.157157о Путівника (дорожньої мапи) для забезпечення успішної протидії захворюванню на туберкульоз на основі комплексного міжвідомчого та 157н.157157остовано157ої157 підходу в умовах переходу на моделі його лікування, орієнтовані на пацієнта в Херсонській області та 157н.157157o Стратегії Міжвідомчої та 157н.157157остовано157ої протидії захворюванню на туберкульоз у Херсонській області, ухвалені Херсонською обласною координаційною радою з питань протидії туберкульозу та ВІЛ-інфекції/СНІД 05 грудня 2018 року.

Путівник розроблено на основі опрацювання міжнародних рекомендацій щодо подолання туберкульозу, чинного законодавства України у сфері протидії захворюванню на туберкульоз, «Уніфікованого клінічного протоколу первинної, вторинної (спеціалізованої) та третинної (високоспеціалізованої) медичної 
допомоги дорослим «Туберкульоз», положень про обласні органи державної влади Херсонської області, а також наукової та науково-популярної літератури 3 туберкульозу [14 та 158н..].

Стратегія міжвідомчої та 158н.158158остовано158ої протидії захворюванню на туберкульоз в Херсонській області являє собою перелік наявних вимог чинної обласної нормативно-правової бази та чинного законодавства, що безпосередньо уповноважують різні органи державної виконавчої влади та органи місцевого самоврядування Херсонської області брати участь (або позначають можливість цього) в реалізації державної політики у сфері протидії захворюванню на туберкульоз та дозволяє скоординувати їі.

Путівник і Стратегія дозволять всім зацікавленим органам державної влади області, іншим сторонам та особам віднайти своє місце у загальнодержавній справі подолання тягаря туберкульозу в Україні, допоможуть окремим групам населення, що мають високий ризик захворювання на туберкульоз, зорієнтуватися iз ситуацією із туберкульозом в Україні та дізнатися, як уберегтися від захворювання, а тим, хто захворів на туберкульоз, дасть змогу зрозуміти свої права й обов’язки та основні правила поведінки на шляху «від кашлю до одужання».

До цього в Херсонській області вже було реалізовано обласну цільову соціальну програму протидії захворювання на туберкульоз на 2013-2016 роки (знято обласною радою з контролю 08 вересня 2017 року) та обласну програму протидії ВІЛ-інфекції/СНІДу на 2015-2018 роки та заходи протидії захворюванню на туберкульоз.

Водночас, слід зазначити, що Херсонська обласна рада так і не спромоглася розробити i затвердити наступну цільову соціальну програму протидії захворюванню на туберкульоз на 2018-2021 роки (мабуть, очікувала ухвалення відповідного Закону), проте Херсонська міська рада таку програму була ухвалила i виконала впродовж трьох років - 2018-2020. Хоча це і не завадило їй у грудні 2020 року ліквідувати, посилаючись на брак коштів, міський протитуберкульозний диспансер попри масований супротив хворих i громадськості.

Далі проаналізуємо фактичний стан справ щодо запобігання і протидії епідемії туберкульозу на Херсонщині. За 9 місяців 2020 року показник захворюваності на туберкульоз на нові випадки туберкульозу (уперше виявлені + рецидиви) становить 46,2 випадку на 100 тис. населення (9 місяців 2019 року 56,6). Зменшення показника на 17,4\% ( Україна: 9 місяців 2020 - 33,0; 9 місяців 2019 - 45,3. Зменшення показника на 27,1\%) [15].

Захворюваність на вперше 158н.158158остовано випадки в Херсонській області становить 34 випадки на 100 тис. населення (зареєстровано 349 нових 
випадків туберкульозу), що на 23,4\% менше ніж у відповідний період минулого року (44,4 на 100 тис. нас. - 460 хворих) (Україна: 9 місяців 2020 року - 27,0 на 100 тис. населення, 9 місяців 2019 року - 37,1; зменшення на 27,2\%) [15].

Зменшення показника захворюваності, як нам видається, пов'язане насамперед зі зменшенням виявлення хворих на туберкульоз та обмеженим доступом до надання медичної допомоги, що зумовлено складною епідемічною ситуацією та запровадженням упродовж 2020 та початку 2021 року обмежувальних заходів у зв'язку з COVID-19; не проводяться обстеження пересувними флюорографами; низька обізнаність населення щодо захворювання на туберкульоз та через стигму (негативна асоціація людини з чим-небудь ганебним, непрестижним, відразливим - 159н.159.) до туберкульозу.

Крім того, попри зниження рівня захворюваності, зростає кількість важких форм туберкульозу: 51,4\% хворих мають деструктивні форми легеневого туберкульозу, 14 хворих - 3 генералізованими формами туберкульозу множинних локалізацій [15].

Обласний показник смертності за 9 місяців 2020 року склав 8,7 на 100 тис. населення, що на 7,4\% менше ніж за 9 місяців 2019 року (показник 9,4). Станом на початок грудня 2020 року показник смертності знизився лише на 0,9\% порівняно з аналогічним періодом 2019 року (з 10,6 до 10,5 випадку на 100 тис. населення). Водночас значно зросла кількість посмертно виявлених випадків туберкульозу серед нових випадків та рецидивів туберкульозу: за 9 місяців 2020 року зареєстровано посмертно 25 осіб, а впродовж 9 місяців 2019 року було зареєстровано 19 таких випадків [15].

У соціальній структурі хворих на туберкульоз на Херсонщині переважає захворюваність серед осіб працездатного віку $(76,1 \%)$, пенсіонерів $(8,5 \%)$, учнів та студентів - 2,9\%, безхатченків 2,9\%. За чинниками впливу на результати лікування хворі, які зловживають алкоголем, становлять 14,3\%, уживають 159н.'єкційні наркотики - 1,8\% [15].

I надалі в області реєструються хворі із лікарсько-стійким туберкульозом. Так, упродовж 9 місяців 2020 року зареєстровано 182 випадки, за аналогічний період 2019 року виявлено 188 таких осіб.

Таблиця 1

Результати лікування нових випадків лікарсько-стійкого туберкульозу 1-3 когорти 2018 року

\begin{tabular}{|l|c|c|c|}
\hline \multicolumn{1}{|c|}{ Показник } & МРТБ (\%) & РР ТБ (\%) & ЛС ТБ (\%) \\
\hline Ефективне лікування & 51,9 & 49,2 & 64,3 \\
\hline Померло & 12,1 & 12,7 & 14,3 \\
\hline Невдале лікування & 16,0 & 19,0 & 7,1 \\
\hline Перервали лікування & 19,9 & 19,0 & 14,3 \\
\hline
\end{tabular}

Складено за [15]. 
Наразі залишається значною питома вага хворих на лікарсько-стійкий туберкульоз, які переривають лікування. Так, 2019 року таких було 11,7\%, 2020 $6,5 \%$. Серед хворих на чутливий туберкульоз цей показник становить 3,7\% та 3,4\% відповідно [15].

Крім того, велика питома вага соціально незахищених груп населення, безробітних та соціально дезадаптованих серед тих, хто захворів, на фоні відсутності соціальної підтримки на амбулаторному етапі лікування призводить до перерв у лікуванні, що впливає на показник ефективності лікування.

Спеціалізовану стаціонарну медичну допомогу хворим на туберкульоз надає єдине в області КНП «Фтизіопульмонологічний медичний центр» Херсонської обласної ради. Амбулаторне лікування за допомогою Інтернет-ресурсів здійснюється на базі амбулаторно- поліклінічного відділення КНП «ФМЦ» ХОР хворих на туберкульоз із міста Херсона та хворих на туберкульоз із районів області за бажанням пацієнта, а також на базі протитуберкульозних кабінетів районних лікарень та підрозділів центрів первинної медичної (медико-санітарної) допомоги (ЦПМСД). Водночас, наразі відсутні лікарі-фтизіатри у Верхньорогачицькому, Великоолександрівському, Каланчацькому, Високопільському, Нижньосірогозькому районах Херсонської області, лише на 0,5 ставки зайнято фтизіатричні посади в Бериславському та Чаплинському районах [15].

Відсутність лікарів-фтизіатрів у районних медичних закладах створює перешкоди для амбулаторного лікування хворих на туберкульоз, які працюють, оскільки листки непрацездатності через туберкульоз мають право видавати лише лікарі-фтизіатри [15].

У Херсонській області 2020 року, як уже зазначалося вище, на тлі неблагополучної ситуації через COVID-19 та запровадження обмежувальних заходів, виникли складнощі в доступі до послуг 3 діагностики та лікування туберкульозу. Невідкладним стало питання організації транспортування біологічного матеріалу для забезпечення діагностики туберкульозу (ТБ) та коінфекції ТБ/ВІЛ-інфекції, доставки протитуберкульозних ліків та препаратів для антиретровірусної терапії в райони області з метою забезпечення неперервності процесу лікування.

Завдячуючи такій необхідній та вчасній підтримці команди міжнародної організації РАТН (міжнародна некомерційна організація, що сприяє поліпшенню здоров’я населення в усьому світі шляхом впровадження оптимальних технологій, зміцнення системи охорони здоров'я та пропаганди здорового способу життя aвm.) у цій складній ситуації в межах проєкту «Підтримка зусиль у протидії туберкульозу в Україні», у Херсонській області було організовано логістичні 
перевезення біологічного матеріалу та протитуберкульозних препаратів. Було затверджено графік та маршрут руху транспорту, укладено договір 3 автотранспортним підприємством та організовано доставку біоматеріалу до лабораторії КНП «Фтизіопульмонологічний медичний центр» Херсонської обласної ради із районів області для проведення повноцінного комплексу бактеріоскопічних, бактеріологічних та молекулярно-генетичних досліджень на туберкульоз, визначення вірусного навантаження для хворих на поєднану патологію туберкульоз/ВІЛ. У частину районів області, у яких ліквідовано протитуберкульозні кабінети, визначені куратори-фтизіатри районів контролюють доставку потрібних лікарських засобів для лікування хворих на туберкульоз та ТБ/ВІЛ за місцем проживання.

Украй актуальним в межах проєкту наразі стало транспортування біологічного матеріалу для дослідження за допомогою методу GenoTyреMTB у Миколаївській області, що набагато скоротило терміни виявлення лікарськостійкого туберкульозу та призначення адекватного лікування. Це вчасне i правильне управлінське рішення, ухвалене з урахуванням фінансової підтримки партнерів, змінило долі багатьох пацієнтів.

Допомога таких надійних та професійних партнерів команди проєкту USAID «Підтримка зусиль у протидії туберкульозу в Україні» надихає та стимулює медичну спільноту області до вдосконалення та підвищення рівня якості діагностики, лікування туберкульозу, та дає надію пацієнтам на швидке одужання.

Завдяки проєкту USAID «Підтримка зусиль у протидії туберкульозу в Україні», що реалізує міжнародна організація РАТН, у кабінетах мікробіологічної лабораторії та в приміщеннях медичного складу обласного центру (КНП «Фтизіопульмонологічний медичний центр» $\mathrm{XOP)} \mathrm{демонтовано} \mathrm{старі} \mathrm{та}$ встановлено 8 сучасних кондиціонерів. Завдяки цьому в приміщеннях, де зберігається вартісне обладнання лабораторії та реактиви, потрібні для якісної лабораторної діагностики туберкульозу, лікарські засоби та витратні матеріали, забезпечено необхідний температурний режим.

Крім того, у межах проєкту надано значну фінансову підтримку для проведення оцінки якості роботи обладнання мікробіологічної лабораторії (валідація шаф біологічної безпеки), що є вкрай важливим у забезпеченні вимог інфекційного контролю та захисту працівників лабораторії від зараження на робочому місці.

\section{Висновки.}

1. Зниження імунітету населення за рахунок поширення ВІЛ-інфекції, широкого використання імуносупресивних (що ослаблюють імунітет 3 тих чи інших причин - aвm.) та цитостатичних (протипухлинні препарати, що 
порушують процеси росту, розвитку та механізми поділу всіх клітин організму, уключаючи злоякісні - aвm.) препаратів, економічне зубожіння та перманентне перебування в умовах хронічного стресу у повсякденному житті та побуті пересічного населення України, невпевненість у завтрашньому дні, воєнні дії на Сході країни, інтенсивна алкоголізація та наркотизація населення, безробіття, значна міграція населення, скорочення та закриття протитуберкульозних стаціонарів, скорочення кількості працівників протитуберкульозної служби (імовірно, це відбувається 3 метою мінімізації витрат на боротьбу з ТБ) роблять прогноз щодо контролю ситуації над перебігом епідемії ТБ в Україні невтішним не виключено погіршення епідеміологічної ситуації з ТБ в найближчих кілька років.

2. Попри зниження захворюваності на туберкульоз упродовж останніх 5 років (2016-2020) статистичні показники залишаються високими, перевищуючи епідемічний поріг, тобто епідеміологічна ситуація із цього інфекційного захворювання залишається складною. Прогнозування за допомогою трендів показує, що суттєвої динаміки епідемії в найближчі 5 років не очікується. Спостерігається зростання захворюваності на туберкульоз у поєднанні зі СНІДом, а також смертності хворих до 1 року спостереження, захворюваності на ТБ контактних осіб. Показники охоплення дорослого населення профілактичними флюорографічними оглядами та дітей віком 0-14 років туберкулінодіагностикою продовжують знижуватися, у зв’язку із цим реальні показники захворюваності значно вищі. Усе це вимагає невідкладних заходів з удосконалення наявної системи виявлення, діагностики, лікування, профілактики туберкульозу.

3. Виходячи з такого стану справ, існує нагальна потреба перегляду та зміни підходів до організації, планування і фінансування програм протидії туберкульозу та ВІЛ-інфекції/СНІДу відповідно до нових глобальних стратегій та керівних документів Всесвітньої організації охорони здоров’я та Об'єднаної програми ООН 3 ВІЛ/СНІДу щодо прискорення відповіді для зупинення епідемій, забезпечення фінансування за рахунок коштів державного та місцевих бюджетів, а також удосконалення стратегії залучення міжнародної технічної допомоги.

4. 3 огляду на особливу соціальну небезпеку туберкульозу державна політика в цьому напрямку (i регіональна в т.ч.) має вирішувати завдання досягнення взаємодії i координації зусиль різних органів державної влади та органів місцевого самоврядування в Україні для протидії туберкульозу з метою сприяння усуненню докорінних соціально-економічних причин поширення епідемії туберкульозу, тобто наріжним каменем сучасної державної політики протидії туберкульозу має стати первинна, або ж соціальна профілактика туберкульозу, до вирішення завдань якої повинно бути залучене широке коло органів державної виконавчої влади та органів місцевого самоврядування. 


\section{Jimepamypa:}

1. Туберкульоз в Україні (Аналітично-статистичний довідник). К.: ДУ «Центр громадського здоров'я Міністерства охорони здоров'я України», 2019.- 45 с.

2. 9-й Регіональний симпозіум з питань лікування туберкульозу в країнах Східної Свропи та Центральної Азії [Електронний ресурс] // Туберкульоз, легеневі хвороби, ВІЛ-інфекція. 2020. - № 2. - С. 78. - Режим доступу: http://nbuv.gov.ua/UJRN/Tlkhvil_2020_2_10

3. Марквас К.Ф. Досвід боротьби з туберкульозом на півдні України у міжвоєнний період (за матеріалами Херсонщини) [Електронний ресурс] / К. Ф. Марквас // Наукові праці історичного факультету Запорізького національного університету. - 2018. - Вип. 50. - С. 293 297. - Режим доступу: http://nbuv.gov.ua/UJRN/Npifznu_2018_50_34

4. Фещенко Ю.І. Сучасні тенденції вивчення проблем туберкульозу [Електронний ресурс] / Ю. І. Фещенко // Український пульмонологічний журнал. - 2019. - № 1. - С. 8-24. - Режим доступу: http://nbuv.gov.ua/UJRN/Upj_2019_1_4

5. Талалаєв К.О. Динаміка змін епідемічної ситуації 3 туберкульозу в областях Причорноморського регіону та в Україні в період з 2006 до 2018 р. [Електронний ресурс] / К. О. Талалаєв, В. С. Гойдик, Р. С. Вастьянов, А. В. Тодорова // Вісник соціальної гігієни та організації охорони здоров’я України. - 2019. - № 2. - С. 10-22. - Режим доступу: http://nbuv.gov.ua/UJRN/VSG_2019_2_4

6. Фещенко Ю.І. Епідеміологічна ситуація з туберкульозу в Україні [Електронний ресурс] / Ю. І. Фещенко, В. М. Мельник, М. І. Гуменюк, М. І. Линник // Infusion \& chemotherapy. - 2019. - № 4. - С. 5-9. - Режим доступу: http://nbuv.gov.ua/UJRN/infch_2019_4_3

7. Тодоріко Л.Д. Прогностичний аналіз ситуації з туберкульозу у світі за результатами щорічної доповіді ВООЗ [Електронний ресурс] / Л. Д. Тодоріко, М. І. Гуменюк, О. С. Шевченко, I. В. Єременчук, І. О. Сем’янів // Infusion \& chemotherapy. - 2019. - № 4. - С. 10-17. Режим доступу: http://nbuv.gov.ua/UJRN/infch_2019_4_4

8. Нагорна А.М. Нормативно-правове регулювання профілактики та надання медичної допомоги хворим на загальний і професійний туберкульоз в Україні [Електронний ресурс] / А. М. Нагорна, І. Г. Кононова, М. П. Соколова // Український журнал з проблем медицини праці. 2020. - T. 16, № 1. - С. 3-16. - Режим доступу: http://nbuv.gov.ua/UJRN/Ujpmp_2020_16_1_3

9. Тодоріко Л.Д. Досягнення та складні питання щодо подолання туберкульозу в Україні (консолідований погляд 3 різних регіонів) [Електронний ресурс] / Л. Д. Тодоріко, В. І. Петренко, Ю. М. Валецький, О. С. Шевченко, І. О. Сем’янів, І. Я. Макойда, М. І. Сахелашвілі, Грищук. А. Л // Туберкульоз, легеневі хвороби, ВІЛ-інфекція. - 2020. - № 1. - С. 10-17. - Режим доступу: http://nbuv.gov.ua/UJRN/Tlkhvil_2020_1_5

10. Про протидію захворювання на туберкульоз: Закон України від 05 липня 2001 року №2586-III (із змінами). URL: https://zakon.rada.gov.ua/laws/show/2586-14\#Text

11. Про схвалення Стратегії забезпечення сталої відповіді на епідемії туберкульозу, в тому числі хіміорезистентного, та ВІЛ-інфекції/СНІДу на період до 2020 року та затвердження плану заходів щодо ії реалізації: Розпорядження Кабінету Міністрів України від 22 березня 2017 року № 248-p. URL: https://zakon.rada.gov.ua/laws/show/248-2017-\%D1\%80\#Text

12. Про схвалення Концепції Загальнодержавної цільової соціальної програми протидії захворюванню на туберкульоз на 2018-2021 роки: розпорядження Кабінету Міністрів України від 27 грудня 2017 року № 1011-p. URL: https://www.kmu.gov.ua/npas/pro-shvalennya-koncepciyizagalnoderzhavnoyi-cilovoyi-socialnoyi-programi-protidiyi-zahvoryuvannyu-na-tuberkuloz-na20182021-roki 
13. Про затвердження Загальнодержавної цільової соціальної програми протидії захворюванню на туберкульоз на 2018-2021 роки: проєкт Закону України, поданий Кабінетом Міністрів України і зареєстрований у Верховній раді України 14 січня 2019 року за № 9467. URL: http://search.ligazakon.ua/1_doc2.nsf/link1/JH7AZ00A.html

14. Про затвердження стандартів охорони здоров'я при туберкульозі [Електронний ресурс] // Туберкульоз, легеневі хвороби, ВІЛ-інфекція. - 2020. - № 2. - С. 53-74. - Режим доступу: http://nbuv.gov.ua/UJRN/Tlkhvil_2020_2_8

15. Поточний архів Департаменту здоров’я Херсонської обласної державної адміністрації за 2019-2020 роки.

\section{References:}

1. Tuberkul'oz v Ukrayini (Analitychno-statystychnyy dovidnyk) - Tuberculosis in Ukraine (Analytical and statistical reference book) K.: DU «Tsentr hromads'koho zdorov"ya Ministerstva okhorony zdorov"ya Ukrayiny» - K .: "Center for Public Health of the Ministry of Health of Ukraine", 2019, 45p. [in Ukrainian].

2. 9-y Rehional'nyy sympozium z pytan' likuvannya tuberkul'ozu v krayinakh Skhidnoyi Yevropy ta Tsentral'noyi Aziyi (Elektronnyy resurs) [9th Regional Symposium on TB Treatment in Eastern Europe and Central Asia (Electronic resource)]. Tuberkul'oz, lehenevi khvoroby, VIL-infektsiya - Tuberculosis, lung diseases, HIV infection, 2020, 2, 78. Retrieved from http://nbuv.gov.ua/UJRN/Tlkhvil_2020_2_10 [in Ukrainian].

3. Markvas K.F. (2018) Dosvid borot'by z tuberkul'ozom na pivdni Ukrayiny u mizhvoyennyy period (za materialamy Khersonshchyny) (Elektronnyy resurs) [Experience of tuberculosis control in the south of Ukraine in the interwar period (according to the materials of Kherson region) (Electronic resource)]. Naukovi pratsi istorychnoho fakul'tetu Zaporiz'koho natsional'noho universytetu Scientific works of the historical faculty of Zaporizhia National University, 50, 293-297. Retrieved from http://nbuv.gov.ua/UJRN/Npifznu_2018_50_34 [in Ukrainian].

4. Feshchenko YU.I. (2019) Suchasni tendentsiyi vyvchennya problem tuberkul'ozu (Elektronnyy resurs) [Modern tendencies of studying the problems of tuberculosis (Electronic resource)]. Ukrayins'kyy pul'monolohichnyy zhurnal - Ukrainian Pulmonological Journal, 1, 8-24. Retrieved from http://nbuv.gov.ua/UJRN/Upj_2019_1_4 [in Ukrainian].

5. Talalayev K.O. (2019) Dynamika zmin epidemichnoyi sytuatsiyi z tuberkul'ozu v oblastyakh Prychornomors'koho rehionu ta v Ukrayini v period z 2006 do 2018 r. (Elektronnyy resurs) [Dynamics of changes in the epidemic situation of tuberculosis in the regions of the Black Sea region and in Ukraine in the period from 2006 to 2018 (Electronic resource)]. K. O. Talalayev, V. S. Hoydyk, R. S. Vast'yanov, A. V. Todorova. Visnyk sotsial'noyi hihiyeny ta orhanizatsiyi okhorony zdorov"ya Ukrayiny - Bulletin of social hygiene and health care organization of Ukraine, 2, 10-22. Retrieved from http://nbuv.gov.ua/UJRN/VSG_2019_2_4 [in Ukrainian].

6. Feshchenko YU.I. (2019) Epidemiolohichna sytuatsiya $\mathrm{z}$ tuberkul'ozu $\mathrm{V}$ Ukrayini (Elektronnyy resurs) [Epidemiological situation of tuberculosis in Ukraine (Electronic resource)]. $Y U$. I. Feshchenko, V. M. Mel'nyk, M. I. Humenyuk, M. I. Lynnyk. Infusion \& chemotherapy, 4, 5-9. Retrieved from http://nbuv.gov.ua/UJRN/infch_2019_4_3 [in Ukrainian].

7. Todoriko L.D. (2019) Prohnostychnyy analiz sytuatsiyi z tuberkul'ozu u sviti za rezul'tatamy shchorichnoyi dopovidi VOOZ (Elektronnyy resurs) [Prognostic analysis of the situation with tuberculosis in the world according to the results of the annual report of the WHO (Electronic resource)]. L. D. Todoriko, M. I. Humenyuk, O. S. Shevchenko, I. V. Yeremenchuk, I. O. Sem"yaniv. 
Infusion \& chemotherapy, 4, 10-17. Retrieved from http://nbuv.gov.ua/UJRN/infch_2019_4_4 [in Ukrainian].

8. Nahorna A.M. (2020) Normatyvnopravove rehulyuvannya profilaktyky ta nadannya medychnoyi dopomohy khvorym na zahal'nyy i profesiynyy tuberkul'oz v Ukrayini (Elektronnyy resurs) [Normative-legal regulation of prevention and provision of medical care to patients with general and professional tuberculosis in Ukraine (Electronic resource)]. A. M. Nahorna, I. H. Kononova, M. P. Sokolova. Ukrayins'kyy zhurnal z problem medytsyny pratsi - Ukrainian Journal of Occupational Medicine, T. 16, 1. 3-16. http://nbuv.gov.ua/UJRN/Ujpmp_2020_16_1_3[in Ukrainian].

9. Todoriko L.D. (2020) Dosyahnennya ta skladni pytannya shchodo podolannya tuberkul'ozu v Ukrayini (konsolidovanyy pohlyad $\mathrm{z}$ riznykh rehioniv) (Elektronnyy resurs) [Achievements and complex issues of overcoming tuberculosis in Ukraine (consolidated view from different regions) (Electronic resource)]. Todoriko, V. I. Petrenko, YU. M. Valets'kyy, O. S. Shevchenko, I. O. Sem"yaniv, I. YA. Makoyda, M. I. Sakhelashvili, Hryshchuk. A. L. Tuberkul'oz, lehenevi khvoroby, VIL-infektsiyaTuberculosis, lung diseases, HIV infection, 1, 10-17. Retrieved from http://nbuv.gov.ua/UJRN/Tlkhvil_2020_1_5 [in Ukrainian].

10. Pro protydiyu zakhvoryuvannya na tuberkul'oz: Zakon Ukrayiny vid 05 lypnya 2001 roku №2586-III (iz zminamy) [On the fight against tuberculosis: Law of Ukraine of July 5, 2001 №2586-III (as amended)]. Retrieved from https://zakon.rada.gov.ua/laws/show/2586-14\#Text [in Ukrainian].

11. Pro skhvalennya Stratehiyi zabezpechennya staloyi vidpovidi na epidemiyi tuberkul'ozu, v tomu chysli khimiorezystentnoho, ta VIL-infektsiyi/SNIDu na period do 2020 roku ta zatverdzhennya planu zakhodiv shchodo yiyi realizatsiyi: Rozporyadzhennya Kabinetu Ministriv Ukrayiny vid 22 bereznya 2017 roku № 248-r [On approval of the Strategy to ensure a sustainable response to the epidemic of tuberculosis, including chemoresistant, and HIV / AIDS for the period up to 2020 and approval of the action plan for its implementation: Order of the Cabinet of Ministers of Ukraine of March 22, 2017 № 248-r]. Retrieved from https://zakon.rada.gov.ua/laws/show/248-2017$\%$ D1\%80\#Text [in Ukrainian].

12. Pro skhvalennya Kontseptsiyi Zahal'noderzhavnoyi tsil'ovoyi sotsial'noyi prohramy protydiyi zakhvoryuvannyu na tuberkul'oz na 2018-2021 roky: rozporyadzhennya Kabinetu Ministriv Ukrayiny vid 27 hrudnya 2017 roku № 1011-r [On approval of the Concept of the National Targeted Social Program to Combat Tuberculosis for 2018-2021: Order of the Cabinet of Ministers of Ukraine of December 27, 2017 № 1011-r]. Retrieved from https://www.kmu.gov.ua/npas/pro-shvalennyakoncepciyi-zagalnoderzhavnoyi-cilovoyi-socialnoyi-programi-protidiyi-zahvoryuvannyu-natuberkuloz-na-20182021-roki [in Ukrainian].

13. Pro zatverdzhennya Zahal'noderzhavnoyi tsil'ovoyi sotsial'noyi prohramy protydiyi zakhvoryuvannyu na tuberkul'oz na 2018-2021 roky: proyekt Zakonu Ukrayiny, podanyy Kabinetom Ministriv Ukrayiny i zareyestrovanyy u Verkhovniy radi Ukrayiny 14 sichnya 2019 roku za № 9467 [On approval of the National Targeted Social Program to Combat Tuberculosis for 2018-2021: Draft Law of Ukraine submitted by the Cabinet of Ministers of Ukraine and registered in the Verkhovna Rada of Ukraine on January 14, 2019 at № 9467]. Retrieved from http://search.ligazakon.ua/l_doc2.nsf/link1/JH7AZ00A.html [in Ukrainian].

14. Pro zatverdzhennya standartiv okhorony zdorov"ya pry tuberkul'ozi (Elektronnyy resurs) [On approval of health standards for tuberculosis (Electronic resource)]. Tuberkul'oz, lehenevi khvoroby, VIL-infektsiya - Tuberculosis, lung diseases, HIV infection, 2020, 2, 53-74. Retrieved from http://nbuv.gov.ua/UJRN/Tlkhvil_2020_2_8 [in Ukrainian]. 
15. Potochnyy arkhiv Departamentu zdorov"ya Khersons'koyi oblasnoyi derzhavnoyi administratsiyi za 2019-2020 roky - Current archive of the Department of Health of the Kherson Regional State Administration for 2019-2020. [in Ukrainian]. 